\title{
Antepartum Course and Follow-up in Patients with Isolated Pyelectasis
}

\author{
A Yasemin Karageyim Karşıdağ, Seda Subaş, Burak Giray, Esra Esim Büyükbayrak
}

Gynecology and Obstetrics, Kartal Dr. Lütfi Kırdar Training and Research Hospital, İstanbul, Turkey

Submitted: 08.01.2015 Accepted: 22.04 .2015

Correspondence: A Yasemin Karageyim Karşıdağ Kozyatağı Mahallesi, Avşar Sokak, No: 46/10, Kadıköy, İstanbul, Turkey

E-mail: ykarageyim@yahoo.com

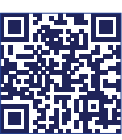

Keywords: Fetal pyelectasis; neonatal uropathy; ultrasonography.

\begin{abstract}
Objective: The present study examined the progression of fetal pyelectasis detected in patients during antenatal period and its relationship to postnatal urinary tract pathology.

Methods: Medical records of 10 patients in whom isolated fetal pyelectasis (defined as anteroposterior [AP] diameter of renal pelvis of $5 \mathrm{~mm}$ or greater in the second trimester and $7 \mathrm{~mm}$ or greater in the third trimester) was detected in prenatal sonographic examination at perinatology clinic between January 2013 and August 2014 were retrospectively reviewed. Fetuses with additional congenital anomalies or aneuploidy were excluded.
\end{abstract}

Results: Nine fetuses were male and I was female. Fetal renal pelvis AP diameter was $<10$ $\mathrm{mm}$ in $5(50 \%), 10-15 \mathrm{~mm}$ in $3(30 \%)$, and $>15 \mathrm{~mm}$ in 2 patients (20\%). Six patients $(60 \%)$ had unilateral and $4(40 \%)$ had bilateral pyelectasis. Progression of pyelectasis in those $4 \mathrm{pa}-$ tients was followed during pregnancy. After birth, ultrasonographic (US) findings of ureteropelvic junction stenosis (UPJ) $(n=I)$, urethrocele $(n=I)$, vesicoureteral reflux (VUR) $(n=I)$, and posterior urethral valves (PUV) and VUR $(n=I)$.

Conclusion: Serial US examinations are important in follow-up of patient with fetal pyelectasis. Progressive and bilateral pyelectasis may be predictive of postnatal uropathy.

\section{INTRODUCTION}

Fetal pyelectasis is defined as isolated dilatation of pelvis not associated with renal calyceal enlargement. ${ }^{[l]}$ Pyelectasia is one of the most frequently encountered abnormalities in antenatal ultrasonographic (US) assessments; it is seen in $1 \%$ to $5 \%$ of pregnancies. ${ }^{[2]}$ Detection of fetal pyelectasis is important in that it is a marker of aneuploidy, and an initial manifestation of urinary system abnormalities. Half of cases with antenatal pyelectasis are transitory physiological events..$^{[3]}$ In the remaining cases, early detection and treatment of urinary system abnormalities can reduce complications. ${ }^{[4]}$ The objective of the present study was to evaluate antenatal course of isolated pyelectasis observed during US monitoring and its association with postnatal urinary system anomalies.

\section{MATERIAL AND METHODS}

Records of newborns with diagnosis of isolated fetal pyelectasis based on antenatal US examinations performed between January 2013 and August 2014 in the perinatology clinic were evaluated retrospectively. It was approved by our hospital's ethics committee. Anteroposterior (AP) renal pelvis diameter used as basis for diagnosis was $\geq 5$ $\mathrm{mm}$ and $\geq 7 \mathrm{~mm}$ in second and third trimesters, respectively. Cases with additional fetal congenital anomalies, fetal chromosomal anomalies, and those that exited during intrauterine life were not included in the study. Eleven of 21 patients who met study criteria but were lost to follow-up were also excluded from the study. Demographic data, US findings, gestational week at diagnosis, and outcome of the pregnancy of 10 patients who were in compliance with 
all the study criteria were examined retrospectively. All newborns underwent urinary US examinations, and sophisticated urological tests were required for babies whose pyelectasis aggravated.

\section{RESULTS}

Mean age of cases with isolated fetal pyelectasis was $29.12 \pm 8.35$ years (range: $20-42$ years), and mean history was gravida 2 (range: I-5), parity I (range: 0-2) (Table I). During diagnostic process, mean gestational week was 26. I $2 \pm 3.39$ weeks (range: $2 \mathrm{I}-3 \mathrm{I}$ weeks), and mean gestational week at birth was 36.87 \pm 1.95 weeks (range: 33-39 weeks). Mean birth weight was $3367.50 \pm 448.68 \mathrm{gr}$ (range: 2100-3620 gr). Nine male and I female newborns constituted the study group. At the time of first diagnosis, AP diameter of renal pelvis was $<10 \mathrm{~mm}$ in $5(50 \%), 10-15$ $\mathrm{mm}$ in 3 (30\%), and > $5 \mathrm{~mm}$ in 2 (20\%) fetuses. Pyelectasis was unilateral in $6(60 \%)$, and bilateral in 4 (40\%) fetuses. Fetal pyelectasis regressed during third trimester in I case, while in 5 fetuses AP diameter did not change (Figure I). In 4 patients, fetal pyelectasis led a progressive course throughout pregnancy. Severe oligohydramnios and progressive pelvicaliectasis were detected in I fetus (Figure 2). Upon decision of the academic council, after corticosteroid therapy, patient gave birth at 33 gestational weeks, and the newborn was diagnosed as postnatal pyelectasis.

Renal US examination was performed for all babies during postnatal period. Five (50\%) newborns had normal findings. Gestational pyelectasis regressed in I case, while in 4 cases diameter of pyelectasic pelvis did not change. In 5 newborns, postnatal pyelectasis was observed. Diameter of pelvis in I case remained the same, while dimensions of pyelectasic pelvis increased in 4 cases. For all newborns, US follow-up was recommended at postnatal I month. Follow-up US findings were within normal limits in 6 newborns, while in 4 babies (whose measurements of pyelectasis progressed during antenatal period), bilateral hydronephrosis was observed which necessitated additional examinations. US revealed ureteropelvic junction (UPJ) stenosis $(n=I)$, urethrocele $(n=I)$, vesicoureteral reflux

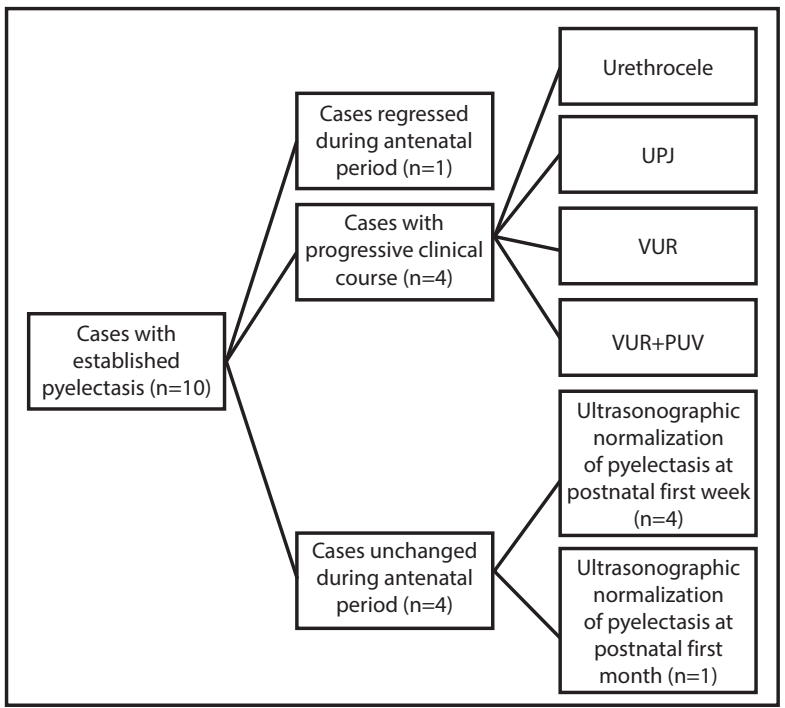

Figure 1. Antenatal clinical course and prognosis of cases with pyelectasis. PUV: Posterior urethral valves; UPJ: Ureteropelvic junction stenosis; VUR: Vesicoureteral reflux.

(VUR) $(n=I)$, and posterior urethral valves (PUV) associated with VUR $(n=I)$ in respective number of patients. Surgical intervention was performed for 2 cases with VUR and patient with urethrocele.

\section{DISCUSSION}

Pyelectasis is one of the most frequently encountered findings during antenatal US examinations. Isolated pyelectasis is generally considered a physiological condition, and can be associated with fetal chromosomal and urinary system abnormalities. ${ }^{[5]}$ Physiological pyelectasis can develop secondary to maternal hydration or gestational hormones. ${ }^{[6]}$ For pelvicaliectasis, most frequently accepted opinion indicates AP diameter of renal pelvis should be $\geq 5$ $\mathrm{mm}$ at any trimester of pregnancy. ${ }^{[7]}$ For cases with pyelectasis that regresses during antenatal period, postnatal monitoring is not recommended. ${ }^{[I]}$ If pyelectasis does not regress and progresses, referral of these pregnant women to centers with pediatric nephrology and pediatric urology

Table I. Demographic characteristics of the patients

\begin{tabular}{lcc}
\hline & Fetal pyelectasis $(\mathbf{n}=\mathbf{1 0})$ & Min.-Max. \\
\hline Maternal age (years) & $29.12 \pm 8.35$ & $20-42$ \\
Gravida & 2 & $1-5$ \\
Parity & 1 & $0-2$ \\
Gestational week at time of diagnosis & $26.12 \pm 3.39$ & $21-31$ \\
Gestational week at birth & $36.87 \pm 1.95$ & $33-39$ \\
Birth weight (gr) & $3367.50 \pm 448.68$ & $2100-3620$ \\
\hline
\end{tabular}




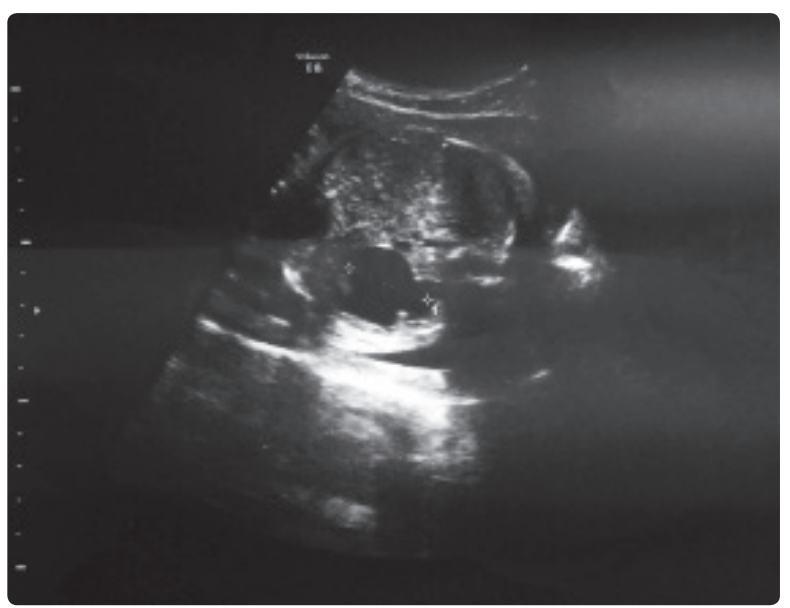

Figure 2. Ultrasonogram of patient whose pregnancy was terminated at $33^{\text {rd }}$ gestational week.

facilities is recommended. ${ }^{[l]}$ While in most cases, urological abnormalities are not detected during postnatal period, urinary system anomalies are seen more frequently in cases of progression of pyelectasis. ${ }^{[1,4,5,8,9]}$ In compliance with the literature, the 4 cases in present study where antenatal pyelectasis progressed, urinary system anomalies were found, and 3 cases underwent surgical intervention. Also in parallel with the literature, ${ }^{[1,4,8,9]}$ pyelectasis was detected more frequently in male fetuses, and the 4 cases with urinary anomalies were of male gender.

Since in newborns the physiologically excreted amount of urine within the first 48-72 hours is very scarce, US examinations performed during this period may reportedly yield false-negative results. ${ }^{[8]}$ However, in severe and bilateral cases of pyelectasis, US images obtained during this period are of crucial importance in order not to overlook cases that require early surgery. ${ }^{[8]}$ In the literature, repeat US examinations have been recommended within the first week and the first month for pyelectasic patients. ${ }^{[7,8]}$ Accordingly, US examinations were performed at the end of the first week and first month for patients with established pyelectasis in present study.

VUR is detected in II\% to $24 \%$ of cases of antenatal pyelectasis. ${ }^{[4,9]}$ If pyelectasis persists through postnatal period, voiding cystourethrography, which is diagnostic for VUR and PUV, should be recommended. ${ }^{[4,8]}$ In present study, VUR was detected in $2(20 \%)$ cases, and PUV in I. UPJ stenosis is one of the most frequently (9\%) reported causes of antenatal pyelectasis, and is generally bilateral. . $^{[4,8,9]}$ Case with diagnosis of postnatal UPJ stenosis in present study had bilateral pyelectasis that led a progressive course during pregnancy. The pregnancy was terminated due to development of severe oligohydramniosis at $33^{\text {rd }}$ gestational week.

As reported in the literature, $28 \%$ of patients diagnosed as antenatal hydronephrosis do not attend follow-up visits. ${ }^{[10]}$ Eleven (52\%) of $2 I$ patients diagnosed by present study authors did not attend follow-up visits and they were not included in the study. Higher rate of lost-to-follow-up may be explained by the fact that the perinatology clinic is a referral center, and after having detailed evaluation and information provided, patients with diagnosis of isolated pyelectasis attended follow-up visits at their former medical centers.

In the monitoring of fetal pyelectasis, serial US examinations are important; presence of bilateral pyelectasis is determinative for postnatal urologic abnormalities. Prenatal diagnosis of pyelectasis allows for early diagnosis and treatment of urinary abnormalities. Newborns with pyelectasis detected during prenatal period should have US evaluation in postnatal period.

\section{REFERENCES}

1. Yamamura Y, Swartout JP, Anderson EA, Knapp CM, Ramin KD. Management of mild fetal pyelectasis: a comparative analysis. J Ultrasound Med 2007;26:1539-43.

2. Odibo AO, Raab E, Elovitz M, Merrill JD, Macones GA. Prenatal mild pyelectasis: evaluating the thresholds of renal pelvic diameter associated with normal postnatal renal function. J Ultrasound Med 2004;23:513-7.

3. Lee RS, Cendron M, Kinnamon DD, Nguyen HT. Antenatal hydronephrosis as a predictor of postnatal outcome: a meta-analysis. Pediatrics 2006;118:586-93.

4. Gürgöze MK, Karaca T. Perinatal Hydronephrosis: Etiology and Effect to Renal Functions. Firat Tip Dergisi 2012;17:139-43.

5. Muhcu M, Gönen G, Akyol İ, Dündar Ö, Tütüncü L, Ergür AR, ve ark. İkinci trimester hafif fetal pyelektazi olgularında antepartum seyir ve postpartum yönetim. Perinatoloji Dergisi 2007;15:56-60.

6. Gunn TR, Mora JD, Pease P. Antenatal diagnosis of urinary tract abnormalities by ultrasonography after 28 weeks' gestation: incidence and outcome. Am J Obstet Gynecol 1995;172(2 Pt 1):479-86.

7. Aksu N, Yavaşcan O, Kangin M, Kara OD, Aydin Y, Erdoğan H, et al. Postnatal management of infants with antenatally detected hydronephrosis. Pediatr Nephrol 2005;20:1253-9.

8. Yavaşcan Ö, Akbay S, Özalkak Ş, Kangın M, Bal A, Can FK, et al. The rate of development postnatal obstructive uropathy in fetal hydronephrosis. Tepecik Eğit Hast Derg 2013;23:65-72.

9. Shamshirsaz AA, Ravangard SF, Egan JF, Prabulos AM, Shamshirsaz AA, Ferrer FA, et al. Fetal hydronephrosis as a predictor of neonatal urologic outcomes. J Ultrasound Med 2012;31:947-54.

10. Woodward M, Frank D. Postnatal management of antenatal hydronephrosis. BJU Int 2002;89:149-56. 


\section{İzole Fetal Piyelektazi Olgularında Antepartum Seyir ve Takip}

Amaç: Antenatal dönemde piyelektazi saptanan olguların doğum öncesi seyri ve postnatal dönemde üriner sistem patolojileriyle ilişkisini göstermek.

Gereç ve Yöntem: Perinatoloji polikliniğinde Ocak 2013 - Ağustos 2014 tarihleri arasında izole fetal piyelektazi tanısı almış (renal pelvis ön arka çapı ikinci trimesterde $\geq 5 \mathrm{~mm}$, üçüncü trimesterde $\geq 7 \mathrm{~mm}$ ) 10 hasta geriye dönük olarak değerlendirildi. Fetal doğumsal anomali ve fetal kromozom anomalisi olan olgular çalışmaya dahil edilmedi.

Bulgular: Fetusların dokuzu erkek, biri kızdı. Renal pelvis ön arka çapı beş hastada (\%50) 10 mm altında, üç hastada (\%30) $10-15$ mm arasında, iki hastada (\%20) 15 mm üzerindeydi. Pyelektazi altı hastada (\%60) tek taraflı, dört hastada (\%40) çift taraflıydı. Dört hastada fetal piyelektazi gebelik süresince ilerleyici seyir izledi. Bir bebekte ureteropelvik bileşek (UPJ) darlığı, bir bebekte üretrosel, bir bebekte vesikoüreteral reflü (VUR) ve bir bebekte hem posterior üretral valv (PUV) hem de VUR saptandı.

Sonuç: Fetal piyelektazi olgularının takibinde seri ultrasonografi önemlidir. İlerleyici ve iki taraflı piyelektazi varlığı postnatal ürolojik anomaliler için belirleyici olabilir.

Anahtar Sözcükler: Fetal piyelektazi, neonatal ürojenital anomali; ultrasonografi. 